\title{
Sunitinib in combination with gemcitabine for advanced solid tumours: a phase I dose-finding study
}

\author{
M D Michaelson *,1 , A X Zhu ${ }^{1}$, D P Ryan ${ }^{1}$, D F McDermott ${ }^{2}$, G I Shapiro ${ }^{3}$, L Tye $^{4}$, I Chen ${ }^{4,6}$, \\ P Stephenson ${ }^{5}$, S Patyna ${ }^{4}$, A Ruiz-Garcia ${ }^{4}$ and A B Schwarzberg ${ }^{1}$ \\ ${ }^{1}$ Massachusetts General Hospital Cancer Center, 55 Fruit Street, Yawkey 7, Boston, MA 02114, USA; ${ }^{2}$ Beth Israel Deaconess \\ Medical Center, 375 Longwood Avenue, Boston, MA 02215, USA; ${ }^{3}$ Dana-Farber Cancer Institute, 450 Brookline Avenue, Boston, \\ MA 02215, USA; ${ }^{4}$ Pfizer Oncology, 10777 Science Center Drive La Jolla, CA 92121, USA and ${ }^{5}$ Rho, Inc., 6330 Quadrangle Drive, \\ Suite 500, Chapel Hill, NC 27517, USA
}

Background: This phase I, dose-finding study determined the maximum tolerated dose (MTD), safety, and pharmacokinetics of sunitinib plus gemcitabine in patients with advanced solid tumours.

Methods: Two schedules with sunitinib (25-50 mg per day) and IV gemcitabine (750-1250 $\mathrm{mg} \mathrm{m}^{-2}$ ) in escalating doses were studied. First, patients received sunitinib on a 4-weeks-on-2-weeks-off schedule (Schedule 4/2) plus gemcitabine on days 1, 8, 22, and 29. Second, patients received sunitinib on a 2-weeks-on-1-week-off schedule (Schedule 2/1) plus gemcitabine on days 1 and 8. The primary endpoint was determination of MTD and tolerability.

Results: Forty-four patients received the combination (Schedule 4/2, $n=8$; Schedule 2/1, $n=36$ ). With no dose-limiting toxicities (DLTs) at maximum dose levels on Schedule 2/1, MTD was not reached. Grade 4 treatment-related AEs and laboratory abnormalities included cerebrovascular accident, hypertension, and pulmonary embolism ( $n=1$ each), and neutropenia $(n=3)$, thrombocytopenia and increased uric acid (both $n=2)$, and lymphopenia $(n=1)$. There were no clinically significant drug-drug interactions. Antitumor activity occurred across dose levels and tumour types. In poor-risk and/or high-grade renal cell carcinoma patients $(n=12), 5$ had partial responses and 7 stable disease $\geqslant 6$ weeks.

Conclusion: Sunitinib plus gemcitabine on Schedule 2/1 with growth factor support was well tolerated and safely administered at maximum doses of each drug, without significant drug-drug interactions.

Therapeutic inhibition of tumour angiogenesis and multiple signalling pathways associated with tumour development (e.g., pathways controlled by vascular endothelial growth factor receptors (VEGFRs) and platelet-derived growth factor receptors (PDGFRs)) results in clinically meaningful antitumor activity, as demonstrated across multiple tumour types, including colon cancer, pancreatic carcinoma, renal cell carcinoma (RCC), breast cancer (BC) and nonsmall-cell lung cancer (NSCLC) (Hurwitz et al, 2005; Sandler et al, 2006; Miller et al, 2007; Burstein et al, 2008; Manegold et al, 2008;
Escudier et al, 2009). When combined with chemotherapy, antiangiogenic therapies may provide effective treatment of historically treatment-resistant solid tumours (Hurwitz et al, 2005; Sandler et al, 2006; Miller et al, 2007; Manegold et al, 2008). Thus, treatment that specifically interrupts tumour vasculature through inhibition of various important receptor tyrosine kinase (RTK) signalling pathways, combined with a chemotherapy, may be of interest.

Sunitinib malate, an oral multitargeted inhibitor of VEGFRs, PDGFRs, stem cell factor receptor (KIT), and other RTKs (Abrams

\footnotetext{
*Correspondence: Dr MD Michaelson; Email: dmichaelson1@partners.org
}

${ }^{6}$ Current address: Aragon Pharmaceuticals, San Diego, CA, USA.

Received 27 September 2012; revised 11 February 2013; accepted 12 February 2013; published online 19 March 2013

(C) 2013 Cancer Research UK. All rights reserved 0007 - 0920/13 
et al, 2003; Mendel et al, 2003; O'Farrell et al, 2003a,b; Faivre et al, 2006), is approved for treatment of advanced RCC, imatinibresistant gastrointestinal stromal tumour, and progressive, welldifferentiated pancreatic neuroendocrine tumours (Demetri et al, 2006; Motzer et al, 2006; Motzer et al, 2007; Kulke et al, 2008; Raymond et al, 2011; SUTENT (sunitinib malate) prescribing information (2012)). In phase I and II trials, sunitinib has also shown antitumor activity in patients with other advanced solid tumours, including BC, NSCLC, neuroendocrine tumour, sarcoma, thyroid cancer and melanoma (Rosen et al, 2003; Faivre et al, 2006; Burstein et al, 2008; Socinski et al, 2008).

Gemcitabine is a nucleoside analogue that primarily targets cells undergoing DNA synthesis (S-phase) and also blocks progression of cells through the G1/S-phase boundary. Gemcitabine is used (alone or in combination with other chemotherapies, such as cisplatin or carboplatin) across a broad spectrum of solid tumours, including locally advanced or metastatic adenocarcinoma of the pancreas, metastatic BC, advanced NSCLC, ovarian cancer, bladder cancer, and others (Gemzar (gemcitabine $\mathrm{HCl}$ ) prescribing information (2010); Gemzar (gemcitabine HCI) product monograph (2006)).

A multitargeted approach for treatment-resistant solid tumours is an attractive strategy. Targeting PDGF and VEGF signalling pathways with sunitinib plus gemcitabine may enhance antitumor activity compared with either agent alone. Extensive preclinical evidence suggests additive and/or synergistic effects in solid tumour models when a variety of chemotherapies, including gemcitabine, are combined with targeted agents, including sunitinib (Yee et al, 2004; Carter et al, 2007; Christensen et al, 2008), as demonstrated in a recently reported phase I trial of sunitinib on a continuous daily dosing schedule plus gemcitabine in patients with advanced solid tumours (Brell et al, 2012). The phase I dose-finding study reported here was also conducted to investigate the safety, pharmacokinetics (PK) and antitumor activity of sunitinib (on an intermittent dosing schedule) in combination with gemcitabine in patients with advanced solid tumours for whom curative therapy was not available. Our study focused on patients with RCC and pancreatic cancer (adenocarcinoma), for whom sunitinib and gemcitabine are standard treatments, respectively.

\section{PATIENTS AND METHODS}

Patients. The population comprised patients aged $\geqslant 18$ years with life expectancy $\geqslant 12$ weeks and Eastern Cooperative Oncology Group (ECOG) performance status 0 or 1 . All patients had histologically proven advanced solid tumours for which curative therapy was not available, had received $\leqslant 1$ prior chemotherapy regimen, and were considered eligible for treatment with standard doses of single-agent gemcitabine. Other inclusion criteria included adequate organ function and haematological parameters without transfusion requirement (erythropoietin or darbepoietin permitted).

Patients were excluded if previously treated with gemcitabine or sunitinib; had severe/unstable angina, myocardial infarction, symptomatic congestive heart failure, cerebrovascular accident, or transient ischaemic attack within the previous 12 months; National Cancer Institute Common Terminology Criteria for Adverse Events (NCI CTCAE, version 3.0) grade 3 haemorrhage within 4 weeks of study entry; uncontrolled hypertension; uncontrolled brain metastases; and a second malignancy diagnosis within the last 5 years.

Study design and treatment. The study (registered with ClinicalTrials.gov, NCT00615446) was conducted at institutions within Dana-Farber/Harvard Cancer Centre (DFHCC) including Massachusetts General Hospital, Dana-Farber Cancer Institute, and Beth
Israel Deaconess Medical Centre. In this phase I, open-label, nonrandomized, dose-finding study, successive cohorts of three patients each received escalating doses of oral sunitinib in combination with escalating doses of intravenous gemcitabine, at starting doses of $37.5 \mathrm{mg}$ and $750 \mathrm{mg} \mathrm{m}^{-2}$, respectively, using a standard $3+3$ design. Sunitinib was administered using one of two once-daily dosing schedules: repeated 6-week cycles consisting of 4 weeks on treatment followed by 2 weeks off (Schedule 4/2), or 3 week cycles consisting of 2 weeks on treatment followed by 1 -week off (Schedule 2/1). Gemcitabine was administered on days 1, 8, 22, and 29 on Schedule $4 / 2$ and on days 1 and 8 on Schedule 2/1 (Figure 1). Planned dose-escalation schemes for sunitinib (both schedules) and gemcitabine are shown in Table 1.

The initial cohorts were expanded to six patients if $1 / 3$ patients experienced a DLT (as defined below) during cycle 1. In addition, up to six additional patients could be included at specific dose levels on either schedule to further define the observed toxicity profile.

Patients were treated until disease progression, unacceptable toxicity, or consent withdrawal. Provision was made for dose reduction if patients experienced drug-related toxicities. The study was performed with approval from the DFHCC institutional review board and in accordance with the Declaration of Helsinki, the International Conference on Harmonisation Good Clinical Practice guidelines, and applicable local regulatory requirements and laws. All patients provided written informed consent.

Dose-limiting toxicity and determination of maximum tolerated dose (MLT). Haematological DLTs were defined as grade 4 neutropenia for $\geqslant 7$ days; febrile neutropenia (fever $>38.5^{\circ} \mathrm{C}$ for $\geqslant 24 \mathrm{~h}$ ); neutropenic infection ( $\geqslant$ grade 3 neutropenia with grade $\geqslant 3$ infection); grade $\geqslant 4$ thrombocytopenia, with bleeding or lasting $\geqslant 7$ days; or lymphopenia accompanied by related infection. Non-haematological DLTs were any drug-related grade 3 or 4 toxicities lasting $\geqslant 7$ days (except for grade $3 / 4$ hyperamylasemia or hyperlipasemia without signs of pancreatitis, grade 4 hyperuricemia or grade $3 / 4$ hypophosphatemia without clinical symptoms, or grade 3 asymptomatic hypertension), and nausea, vomiting, or diarrhoea persisting at grade 3 or 4 despite treatment.

The MTD was defined as the highest dose at which $0 / 6$ or $1 / 6$ patients experienced a DLT during the first 36 or 21 days of cycle 1 (Schedule $4 / 2$ or $2 / 1$, respectively), with the next higher dose having at least $2 / 3$ or $2 / 6$ patients experiencing a DLT. Additional patients could be enrolled at the MTD to further characterise safety and tolerability at that dose level.

Changes to study design and treatment. Schedule $4 / 2$ was not evaluated past the initial combination dose level (sunitinib $37.5 \mathrm{mg}$ and gemcitabine $750 \mathrm{mg} \mathrm{m}^{-2}$ ) as it proved to be an awkward scheduling regimen in practice because of missed or delayed doses of gemcitabine (see Determination of MTD). After moving to the Schedule 2/1 dose-escalation phase, the original protocol was amended to allow use of growth factor support. On day 8, if absolute neutrophil count (ANC) was >1000 cellsper $\mathrm{mm}^{3}$, gemcitabine was given as scheduled. If ANC was between 500 and 1000 cells per $\mathrm{mm}^{3}$ with no signs and symptoms of infection, gemcitabine was given as scheduled and growth factor administration (Neulasta; pegfilgrastim) occurred 1 day later. If ANC was $<500$ cells per $\mathrm{mm}^{3}$, then the gemcitabine dose was held. Missed doses of day 8 gemcitabine were not made up.

Study endpoints. The primary objective was to assess the MTD and overall safety and tolerability of sunitinib administered in combination with gemcitabine in patients with advanced solid tumours. Secondary objectives included evaluation of the antitumor activity and determination of the PK profiles of sunitinib, its active metabolite (SU12662), total drug (sunitinib + SU12662), and 
A

Cycle 1

Sunitinib for 4 weeks

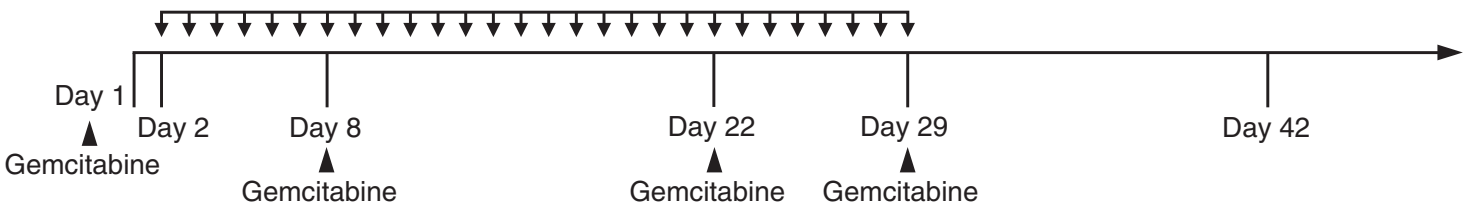

Cycle 2+

Sunitinib for 4 weeks

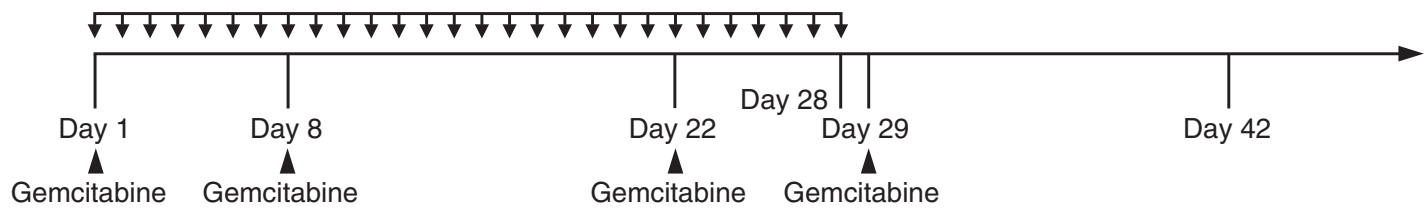

B Cycle 1

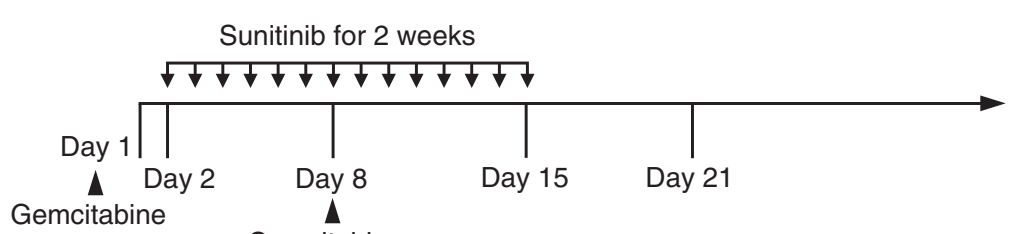

Gemcitabine

Cycle 2+

Sunitinib for 2 weeks

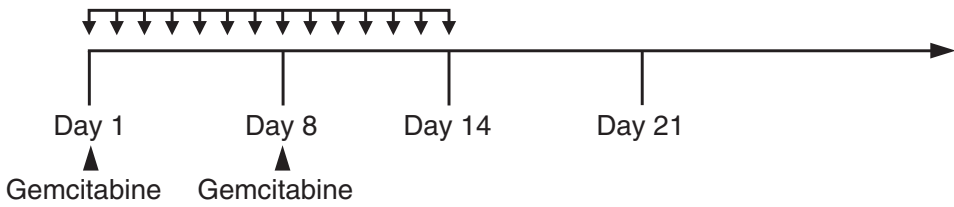

Figure 1. Study schema for (A) Schedule 4/2 and (B) Schedule 2/1.

gemcitabine and its main metabolite $\left(2^{\prime}\right.$-deoxy- $2^{\prime}, 2^{\prime}$-difluorouridine; $\mathrm{dFdU})$, when given in combination.

Study assessments. Safety assessment included AE monitoring with severity graded according to NCI CTCAE, Version 3.0, and urinalysis, clinical laboratory tests (haematology and blood chemistry), physical examinations, and 12-lead electrocardiogram, all scheduled at regular intervals. Objective tumour response was assessed according to Response Evaluation Criteria in Solid Tumours (RECIST Version 1.0) (Therasse et al, 2000). Radiological tumour assessments were performed at screening and on day 29 of cycle 1 and even cycles thereafter (Schedule 4/2), week 3 of cycles 2 , 4 , and every 4 cycles thereafter (Schedule $2 / 1$ ), whenever disease progression was suspected, and to confirm response.

Blood samples for determination of full PK profiles for sunitinib and SU12662 were collected for patients receiving Schedule $4 / 2$ on cycle 1, day 15 (sunitinib alone) and day 22 (sunitinib and gemcitabine), and for patients receiving Schedule $2 / 1$ on cycle 1 , day 8 (sunitinib and gemcitabine) and day 15 (sunitinib alone) at pre-dose and up to $25 \mathrm{~h}$ post-dose. In addition, blood samples for determination of trough levels of sunitinib and SU12662 were taken for Schedule $4 / 2$ pre-dose on day 1 (cycles $1-3$ ) and $24 \mathrm{~h}$ after the last dose (cycles 1-3 and 5), and for Schedule $2 / 1$ were obtained before dosing on day 1 (cycles 1,4 , and 6), days 8 and 15 (cycle 1) and day 14 (cycles 4, 6, and 10). For gemcitabine and $\mathrm{dFdU}$ PK profiles, blood samples were drawn pre-dose and up to $9 \mathrm{~h}$ after the start of infusion on cycle 1 , days 1 and 22 (with
Table 1. Dose escalation scheme

\begin{tabular}{|c|c|c|}
\hline & \multicolumn{2}{|c|}{ Dose level } \\
\hline & $\begin{array}{c}\text { Gemcitabine } \\
\left(\mathrm{mg} \mathrm{m}^{-2}\right)\end{array}$ & Sunitinib (mg) \\
\hline \multicolumn{3}{|l|}{ Schedule $4 / 2$} \\
\hline $\begin{array}{l}-2 \\
-1 \\
1 \text { (Starting dose) } \\
2 \\
3 a \\
3 \\
4 a \\
4\end{array}$ & $\begin{array}{c}600 \\
600 \\
750 \\
750 \\
850 \\
850 \\
1000 \\
1000\end{array}$ & $\begin{array}{c}25 \\
37.5 \\
37.5 \\
50 \\
37.5 \\
50 \\
37.5 \\
50\end{array}$ \\
\hline \multicolumn{3}{|l|}{ Schedule 2/1 } \\
\hline $\begin{array}{l}-2 \\
-1 \\
1 \text { (Starting dose) } \\
2 \\
3 \\
4 \\
5 \\
6\end{array}$ & $\begin{array}{c}600 \\
600 \\
750 \\
850 \\
1000 \\
1000 \\
1250 \\
1250 \\
\end{array}$ & \begin{tabular}{c|c|}
25 \\
37.5 \\
37.5 \\
37.5 \\
37.5 \\
50 \\
37.5 \\
50 \\
\end{tabular} \\
\hline
\end{tabular}


sunitinib on Schedule 4/2) or on cycle 1 , days 1 and 8 (with sunitinib on Schedule 2/1).

Statistical methods. The population for all analyses included enrolled patients who received $\geqslant 1$ dose of study medication. Owing to the exploratory nature of the study, no confirmatory inferential analyses were planned and descriptive statistics were used to summarise patient characteristics, treatment administration/compliance, efficacy, and safety. Pharmacokinetics parameters were calculated for each subject by noncompartmental analysis of concentration-time data using WinNonlin version 4.1.

\section{RESULTS}

Baseline patient characteristics and treatment. In total, 44 patients were enrolled: 8 on Schedule $4 / 2$ and 36 on Schedule $2 / 1$. Of the 36 patients on Schedule 2/1, 11 were enrolled before the protocol amendment that allowed the use of growth factor support and 25 were enrolled post-amendment. Eleven patients total (all on Schedule 2/1) received growth factor support, including one patient before the amendment. Baseline patient characteristics (all patients and patients treated on Schedule 2/1, post-amendment) are summarised in Table 2 . The most common primary tumour types were RCC (52\%) and pancreatic cancer (30\%).

Patients treated on Schedule 4/2 and Schedule 2/1, pre- and post-amendment, began a median of 3 cycles (range 1-8), 4 cycles (range 1-9), and 9 cycles (range 2-17), respectively. Median days on sunitinib treatment were 92,84 , and 83-254 (depending on the dose level), respectively, and the median relative dose intensity for sunitinib was $58.4,72.9$, and $77.4-100 \%(67.8,75.0$, and $87.6-100 \%$ for gemcitabine). Sunitinib dose interruptions occurred in 62.5, 63.6, and $33.3-100 \%$, and sunitinib dose reductions occurred in $12.5,18.2$, and $0-75.0 \%$.

Fifty per cent or more of patients were on treatment for more than 6 months at all dose levels, except the lowest (sunitinib $37.5 \mathrm{mg}$ plus $750 \mathrm{mg} \mathrm{m}^{-2}$ ).

Determination of MTD. One of eight patients on Schedule 4/2 experienced a DLT (grade 3 neutropenia) at the initial dose level of sunitinib $37.5 \mathrm{mg}+$ gemcitabine $750 \mathrm{mg} \mathrm{m}^{-2}$, warranting further dose escalation. However, several patients treated on this regimen either missed or had delayed doses of gemcitabine because of slow recovery from neutropenia, and it was decided not to pursue this regimen further. Two of eleven patients $(18 \%)$ on Schedule $2 / 1$, preamendment, had DLTs at the dose level of sunitinib $37.5 \mathrm{mg}+$ gemcitabine $750 \mathrm{mg} \mathrm{m}^{-2}$ (appendicitis/abscess and QTc prolongation). Following the amendment allowing growth factor support, no further protocol-defined DLTs were observed. Dose escalation proceeded to the maximum planned dose level of sunitinib $50 \mathrm{mg}$ and gemcitabine $1,250 \mathrm{mg} \mathrm{m}^{-2}$; further dose escalation was not tested as these are the highest approved doses for each agent individually.

Adverse events. The most common treatment-emergent (all causality) non-haematological AEs (all schedules, all doses) were fatigue (75.0\%), gastrointestinal disorders (nausea, vomiting, diarrhoea, constipation (each $45.5 \%)$ ), and pyrexia (45.5\%), the majority grade 1 or 2 in severity. The most common haematological toxicities were neutropenia (54.6\%), thrombocytopenia (50.0\%), leucopenia (34.1\%), and anaemia (38.6\%). The sunitinib dose was interrupted in 25 patients and reduced in 12 patients across all cohorts. The gemcitabine dose was not modified in any patients. Seven patients died on study, six related to disease progression and one to liver failure (hepatotoxicity has been observed with sunitinib; SUTENT (sunitinib malate) prescribing information (2012)). All deaths were considered unrelated to study treatment as assessed by investigators.
Table 2. Patient characteristics at baseline

\begin{tabular}{|l|c|c|}
\cline { 2 - 3 } & \multicolumn{2}{|c|}{ No. of patients (\%) } \\
\hline & $\begin{array}{c}\text { All patients } \\
(\mathbf{N}=44)\end{array}$ & $\begin{array}{c}\text { Schedule 2/1 } \\
\text { post-amendment } \\
(\mathbf{N}=25)\end{array}$ \\
\hline $\begin{array}{l}\text { Characteristic } \\
\text { years }\end{array}$ & $55.5(27-77)$ & $58(41-77)$ \\
Male/female & $33 / 11(75 / 25)$ & $20 / 5(80 / 20)$ \\
\hline
\end{tabular}

\begin{tabular}{l|c|c|}
\hline \multicolumn{2}{|l|}{ Race } \\
\hline White & $37(84)$ & $22(88)$ \\
Black & $2(5)$ & 0 \\
Asian & $4(9)$ & $2(8)$ \\
Not listed & $1(2)$ & $1(4)$
\end{tabular}

ECOG performance status

\begin{tabular}{|l|c|c|}
\hline 0 & $15(34)$ & $9(36)$ \\
1 & $29(66)$ & $16(64)$ \\
\hline
\end{tabular}

Primary tumour types

RCC

Clear cell

Non-clear cell

Pancreatic cancer

Adenocarcinoma

Ductal adenocarcinoma

Other tumour type

Adenocarcinoma

Carcinoma

Dedifferentiated

Soft tissue and lung

Mesothelioma

Unknown

23 (52)

$10(23)$

$13(30)$

13 (30)

$10(23)$

$3(7)$

8 (18)

$3(7)$

$1(2)$

1 (2)

1 (2)

1 (2)

1 (2)

$14(56)$
$6(24)$
$8(32)$
$5(20)$
$5(20)$
0
$6(24)$
$1(4)$
$1(4)$
$1(4)$
$1(4)$
$1(4)$
$1(4)$

Previous treatment

Surgeryc

Radiotherapy

Prior systemic therapy

1 treatment

$\geqslant 2$ treatments

$43(98)$

9 (20)

15 (34)

14 (32)

1 (2)

25 (100)

6 (24)

7 (28)

7 (28)

0

Abbreviations: $\mathrm{ECOG}=$ Eastern Cooperative Oncology Group; $\mathrm{RCC}=$ renal cell carcinoma.

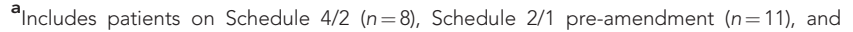
Schedule 2/1 post-amendment $(n=25)$.

${ }^{\mathbf{b}_{\text {Schedule }}} 2 / 1$ study design was amended in order to allow use of growth factor support during cycle 1 , if necessary.

'Surgery includes diagnostic procedures.

Among the eight patients treated on Schedule 4/2, the only treatment-related non-haematological grade $\geqslant 3$ AEs were grade 3 fatigue $(n=1)$ and increased lipase $(n=1)$. Laboratory abnormalities included grade 3 neutropenia $(n=4)$, anaemia $(n=1)$, and thrombocytopenia $(n=1)$.

On Schedule 2/1, pre-amendment, treatment-related nonhaematological grade $\geqslant 3$ AEs for sunitinib $37.5 \mathrm{mg}$ plus gemcitabine $750 \mathrm{mg} \mathrm{m}^{-2}$ were nausea, diarrhoea, vomiting, abscess, appendicitis, electrocardiogram QT-prolongation, hyperamylasemia (each $n=1$ ), and hyperlipasemia $(n=2)$. For the patient with grade 3 QT-prolongation, which began on cycle 1, day 8 , the AE resolved after sunitinib dose interruption for 3 days and dose reduction. Haematological AEs were neutropenia (grade 3 $(n=1)$ and grade $4(n=2))$ and leucopenia (grade $3(n=2))$. No grade 5 events occurred. 


\begin{tabular}{|c|c|c|c|c|c|c|c|c|c|c|c|c|c|c|c|c|c|c|}
\hline \multirow{3}{*}{$\begin{array}{l}\text { Dose level (sunitinib/ } \\
\text { gemcitabine) }\end{array}$} & \multicolumn{18}{|c|}{ No. of patients } \\
\hline & \multicolumn{3}{|c|}{$\begin{array}{c}37.5 \mathrm{mg} / \\
750 \mathrm{mg} \mathrm{m}^{-2} \\
(n=3)\end{array}$} & \multicolumn{3}{|c|}{$\begin{array}{c}37.5 \mathrm{mg} / \\
850 \mathrm{mg} \mathrm{m}^{-2} \\
(n=3)\end{array}$} & \multicolumn{3}{|c|}{$\begin{array}{c}37.5 \mathrm{mg} / \\
1000 \mathrm{mg} \mathrm{m}^{-2} \\
(n=3)\end{array}$} & \multicolumn{3}{|c|}{$\begin{array}{c}37.5 \mathrm{mg} / \\
1250 \mathrm{mg} \mathrm{m}^{-2} \\
(n=3)\end{array}$} & \multicolumn{3}{|c|}{$\begin{array}{c}50 \mathrm{mg} / \\
1000 \mathrm{mg} \mathrm{m}^{-2} \\
(n=4)\end{array}$} & \multicolumn{3}{|c|}{$\begin{array}{c}50 \mathrm{mg} / \\
1250 \mathrm{mg} \mathrm{m}^{-2} \\
(n=9)\end{array}$} \\
\hline & G 3 & G 4 & Any $\mathrm{G}$ & G 3 & G 4 & Any G & G 3 & G 4 & Any $\mathrm{G}$ & G 3 & G 4 & Any G & G 3 & G 4 & Any G & G 3 & G 4 & Any G \\
\hline Neutropenia & 2 & 0 & 2 & 1 & 1 & 3 & 1 & 1 & 2 & 1 & 0 & 2 & 2 & 1 & 3 & 3 & 0 & 3 \\
\hline Lymphopenia & 2 & 0 & 2 & 0 & 1 & 2 & 0 & 0 & 0 & 1 & 0 & 1 & 2 & 0 & 3 & 1 & 0 & 1 \\
\hline Thrombocytopenia & 0 & 0 & 2 & 1 & 1 & 3 & 1 & 0 & 3 & 0 & 0 & 2 & 2 & 0 & 3 & 1 & 1 & 4 \\
\hline Leucopenia & 1 & 0 & 2 & 2 & 0 & 3 & 1 & 0 & 2 & 1 & 0 & 1 & 2 & 0 & 3 & 1 & 0 & 2 \\
\hline Cerebrovascular accident & 0 & 0 & 0 & 0 & 0 & 0 & 0 & 0 & 0 & 0 & 0 & 0 & 0 & 0 & 0 & 0 & 1 & 1 \\
\hline Hypertension & 0 & 0 & 0 & 0 & 0 & 1 & 0 & 0 & 0 & 1 & 1 & 2 & 0 & 0 & 0 & 0 & 0 & 0 \\
\hline Leukoencephalopathy & 0 & 0 & 0 & 0 & 0 & 0 & 0 & 0 & 0 & 0 & 0 & 0 & 1 & 0 & 1 & 0 & 0 & 0 \\
\hline Mucosal inflammation & 0 & 0 & 0 & 0 & 0 & 0 & 0 & 0 & 0 & 0 & 0 & 0 & 0 & 0 & 0 & 1 & 0 & 2 \\
\hline Nausea & 0 & 0 & 1 & 0 & 0 & 2 & 0 & 0 & 1 & 0 & 0 & 1 & 1 & 0 & 4 & 0 & 0 & 7 \\
\hline Pericardial effusion & 0 & 0 & 0 & 0 & 0 & 0 & 0 & 0 & 0 & 1 & 0 & 1 & 0 & 0 & 0 & 0 & 0 & 0 \\
\hline Pulmonary embolism & 0 & 1 & 1 & 0 & 0 & 0 & 0 & 0 & 0 & 0 & 0 & 0 & 0 & 0 & 0 & 0 & 0 & 0 \\
\hline Amylase increase & 0 & 0 & 0 & 0 & 0 & 0 & 0 & 0 & 2 & 1 & 0 & 1 & 1 & 0 & 1 & 0 & 0 & 0 \\
\hline Hypomagnesemia & 0 & 0 & 0 & 0 & 0 & 0 & 0 & 0 & 0 & 0 & 0 & 0 & 0 & 0 & 0 & 1 & 0 & 1 \\
\hline Hypophosphatemia & 0 & 0 & 0 & 0 & 0 & 2 & 0 & 0 & 1 & 0 & 0 & 0 & 0 & 0 & 1 & 1 & 0 & 1 \\
\hline Lipase increase & 0 & 0 & 0 & 0 & 0 & 0 & 0 & 0 & 0 & 1 & 0 & 1 & 0 & 0 & 1 & 0 & 0 & 0 \\
\hline Uric acid increase & 0 & 0 & 0 & 0 & 1 & 1 & 0 & 0 & 2 & 0 & 0 & 0 & 0 & 1 & 1 & 0 & 0 & 0 \\
\hline
\end{tabular}

Treatment-related AEs (grade $\geqslant 3$ ) occurring among the 25 patients on Schedule 2/1, post-amendment, are detailed in Table 3. The most common grade 3 or 4 haematological toxicities related to sunitinib plus gemcitabine treatment in patients on Schedule $2 / 1$, post-amendment, were neutropenia $(n=13)$, leucopenia $(n=8)$, and lymphopenia and thrombocytopenia (both $n=7$ ). Nonhaematological treatment-related AEs included: grade 4 uric acid elevation $(n=2)$, hypertension, pulmonary embolism, and cerebrovascular accident $(n=1$ each), grade 3 elevation of amylase $(n=2)$ or lipase $(n=1)$, hypertension, pericardial effusion, leukoencephalopathy, nausea, mucosal inflammation, hypophosphatemia, and hypomagnesemia (each $n=1$ ).

Pharmacokinetics. Pharmacokinetics data were evaluated for dose levels 1-6 of Schedule 2/1 (Table 1). Plasma PK parameters and geometric mean ratios for subjects with paired observations for sunitinib, SU12662, total drug, gemcitabine and dFdU, as a single agent or in combination, are summarised for all dose levels combined in Table 4 (plasma concentration time curves for patients on Schedule 2/1 are shown in Supplementary Figure 1). The slightly lower sunitinib and total drug $\mathrm{C}_{\max }$ and $\mathrm{AUC}_{24}$ values for sunitinib plus gemcitabine (i.e., on day 8) as compared with sunitinib alone (i.e., on day 15) is likely because of sunitinib and its metabolite not achieving complete steady-state levels by day 8 (sunitinib half-life is $40-86 \mathrm{~h}$ ) (Faivre et al, 2006). This would explain the lower sunitinib exposure at day 8 compared with day 15 when steady state concentrations were achieved. However, overall, there was no evidence of clinically relevant drug-drug interaction between sunitinib and gemcitabine based on drug exposure at any dose level.

Efficacy. Overall, of the total population $(n=44), 8$ patients $(18 \%)$ had an objective response, including 7 of 25 patients (28\%) on
Schedule 2/1, post-amendment (Table 5). A further 18 patients (41\%), including $12(48 \%)$ on schedule $2 / 1$, post-amendment, had stable disease (s.d.) ranging from 10.3 to 47.9 weeks, yielding clinical benefit rates of 59\% (total population) and 76\% (Schedule $2 / 1$ post-amendment), respectively.

Among 25 patients on Schedule 2/1, post amendment, PRs were observed in 7 patients across the full range of doses: two with pancreatic carcinoma and five with RCC. s.d. of median 29.1 weeks (range 11.1-47.9) was experienced by an additional 12/25 patients.

Efficacy in RCC. Across all schedules and cohorts, 6/23 patients (26\%) with RCC achieved a PR and 13 patients (57\%) exhibited s.d. lasting 6 weeks or longer, including 4 patients with s.d. $>6$ months. The majority who failed to achieve any clinical benefit had either papillary or chromophobe histology. Twelve of the RCC patients were either poor risk based on the Memorial Sloan-Kettering Cancer Centre (MSKCC) criteria (Motzer et al, 2002) or had disease that was characterised histologically by sarcomatoid differentiation or Fuhrman grade 4/4 features. Among these twelve patients, five achieved a PR and seven had SD.

\section{DISCUSSION}

We conducted a phase I dose-escalation study of sunitinib combined with gemcitabine in patients with advanced solid tumours. Our results indicate that oral sunitinib given on Schedule $2 / 1$ combined with IV gemcitabine given on days 1 and 8 , with each agent at the maximum individual approved dose, has a favourable safety profile. Schedule $4 / 2$ was not pursued beyond the initial dose level of sunitinib $37.5 \mathrm{mg}$ plus gemcitabine $750 \mathrm{mg} \mathrm{m}^{-2}$ 
Table 4. Pharmacokinetic parameters for sunitinib, its active metabolite (SU12662), and total drug (sunitinib plus SU12662), and gemcitabine and its main metabolite ( $d F d U)$ in patients treated on Schedule 2/1 (subjects with paired observations only)

\begin{tabular}{|c|c|c|c|c|c|}
\hline Analyte & Parameter & $\begin{array}{c}\text { Mean (CV\%) } \\
\text { sunitinib alone, } \\
\text { C1D15 (median) }\end{array}$ & $\begin{array}{c}\text { Mean (CV\%) } \\
\text { gemcitabine alone, } \\
\text { C1D1 (median) }\end{array}$ & $\begin{array}{c}\text { Mean (CV\%) sunitinib } \\
\text { plus gemcitabine, } \\
\text { C1D8 (Median) }\end{array}$ & $\begin{array}{l}\text { Geometric mean } \\
\text { ratio (combination } \\
\text { vs sunitinib alone) }\end{array}$ \\
\hline \multicolumn{6}{|c|}{ All dose cohorts combined $(n=32)^{a}$} \\
\hline SU12662 & $\begin{array}{c}C_{\max }, \mathrm{ng} \mathrm{ml}^{-1} \\
\mathrm{AUC}_{24}, \mathrm{ng} \mathrm{h} \mathrm{ml}^{-1} \\
T_{\max }, \mathrm{h}^{\mathbf{b}} \\
\mathrm{CL} / \mathrm{F}, \mathrm{Ih}^{-1} \\
C_{\max }, \mathrm{ng} \mathrm{ml}^{-1} \\
\mathrm{AUC}_{24}, \mathrm{ng} \mathrm{h} \mathrm{ml}^{-1} \\
T_{\max }, \mathrm{h}^{\mathbf{b}}\end{array}$ & $\begin{array}{c}63.6(43)(56.6) \\
1241(46)(1113) \\
4.0(0.0-9.0) \\
47.0(37)(44.9) \\
19.4(51)(15.7) \\
411(51)(333) \\
4.0(0.0-24.0)\end{array}$ & $\begin{array}{l}- \\
- \\
- \\
- \\
- \\
-\end{array}$ & $\begin{array}{c}71.5(58)(60.0) \\
1445(52)(1282) \\
7.0(3.0-24.0) \\
41.4(37)(39.0) \\
27.5(68)(20.6) \\
596(71)(453) \\
4.0(0.0-24.0)\end{array}$ & $\begin{array}{l}0.92 \\
0.87 \\
\text { N/A } \\
1.14 \\
0.74 \\
0.73 \\
\text { NA }\end{array}$ \\
\hline $\begin{array}{l}\text { Total drug } \\
\text { (sunitinib + SU12662) }\end{array}$ & $\begin{array}{c}C_{\max }, \mathrm{ng} \mathrm{ml}^{-1} \\
\mathrm{AUC}_{24}, \mathrm{ng} \mathrm{h} \mathrm{ml}^{-1} \\
T_{\max }, \mathrm{h}^{\mathbf{b}}\end{array}$ & $\begin{array}{c}82.4(38)(71.0) \\
1653(40)(1485) \\
4.0(0.0-24.0)\end{array}$ & $\begin{array}{l}- \\
- \\
-\end{array}$ & $\begin{array}{c}98.3(53)(82.2) \\
\\
2043(49)(1736) \\
7.0(3.0-24.0)\end{array}$ & $\begin{array}{l}0.87 \\
0.83 \\
\text { NA }\end{array}$ \\
\hline \multicolumn{6}{|c|}{ All dose cohorts combined $(n=30)^{a}$} \\
\hline Gemcitabine & $\begin{array}{c}C_{\max }, \mu \mathrm{g} \mathrm{ml}^{-1} \\
\mathrm{AUC}_{\infty}, \mu \mathrm{g} \mathrm{h} \mathrm{ml}^{-1} \\
T_{\max }, \mathrm{h}^{\mathbf{b}} \\
\mathrm{CL}, \mathrm{Ih}^{-1} \\
t_{1 / 2}, \mathrm{~h} \\
C_{\max }, \mu \mathrm{g} \mathrm{ml}^{-1} \\
\mathrm{AUC}_{24}, \mu \mathrm{gh} \mathrm{ml}^{-1} \\
T_{\max }, \mathrm{h}^{\mathbf{b}}\end{array}$ & $\begin{array}{l}- \\
- \\
- \\
- \\
- \\
- \\
-\end{array}$ & $\begin{array}{c}20.9(25)(20.7) \\
10.5(30)(10.5) \\
0.25(0.3-0.5) \\
262(38)(240) \\
0.26(20)(0.26) \\
45.3(17)(44.9) \\
268(29)(248) \\
0.5(0.3-1.5)\end{array}$ & $\begin{array}{c}25.0(36)(24.4) \\
12.6(36)(12.8) \\
0.25(0.3-0.5) \\
225(44)(203) \\
0.29(23)(0.27) \\
50.8(22)(49.7) \\
272(31)(254) \\
0.5(0.5-1.5)\end{array}$ & $\begin{array}{l}1.16 \\
1.18 \\
\text { NA } \\
0.84 \\
\text { NA } \\
1.11 \\
1.01 \\
\text { NA }\end{array}$ \\
\hline \multicolumn{6}{|c|}{ 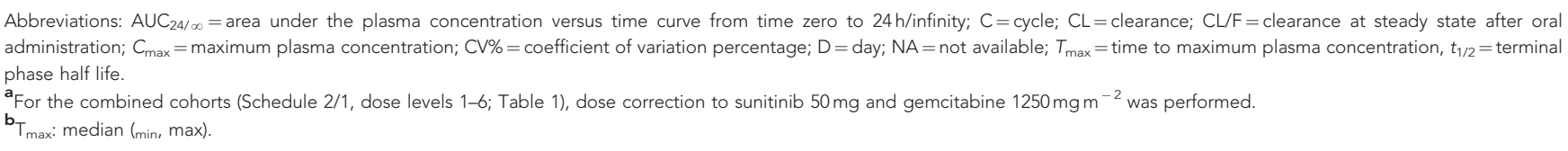 } \\
\hline
\end{tabular}

for practical reasons (i.e., because of missed or delayed doses of gemcitabine because of slow recovery from neutropenia). The study design was modified on Schedule 2/1 to allow growth factor support during cycle 1 . No DLTs occurred at the maximum doses on Schedule 2/1, post-amendment, and most AEs were grade 1 or 2 .

This safety profile is similar to that reported in phase I trials of sunitinib in combination with other chemotherapy regimens, including docetaxel, capecitabine, pemetrexed, carboplatin plus paclitaxel, and gemcitabine (with and without cisplatin), in which most AEs were mild to moderate in studies including patients with all solid tumours or those restricted to NSCLC (Sweeney et al, 2007; Chow et al, 2008; Heath et al, 2008; Traynor et al, 2008; Reck et al, 2010; Brell et al, 2012; Okamoto et al, 2012). In the earlier phase I trial with gemcitabine, growth factor support was excluded and the recommended phase II dose was gemcitabine $675 \mathrm{mg} \mathrm{m}^{-2}$ on days 1 and 8 and sunitinib $25 \mathrm{mg}$ on continuous daily dosing (Brell et al, 2012). However, the most common challenge in drug tolerability, as expected with this combination and also reported previously (Reck et al, 2010), was haematological toxicity, particularly with regard to day 8 administration of gemcitabine, but was manageable with growth factor support. For example, the incidences of the most common grade 3 or 4 haematological toxicities associated with this combination (Schedule $2 / 1$, postamendment) were substantially higher than that with sunitinib monotherapy (in treatment-naïve patients with metastatic RCC; SUTENT (sunitinib malate) prescribing information (2012)): neutropenia (52\% vs $17 \%$, respectively), leucopenia (32\% vs $8 \%$ ), lymphopenia (28\% vs $18 \%$ ) and thrombocytopenia (28\% vs $9 \%$ ). Clinically significant non-haematological AEs were rare and no treatment-related deaths were observed despite the advanced nature of the patient population. In contrast, increases in grade 3 or higher non-haematological toxicity were reported for the combination of sunitinib plus erlotinib in a phase III trial of NSCLC (Scagliotti et al, 2012).

There appeared to be no clinically relevant changes in the PK of sunitinib and total drug when sunitinib was administered with gemcitabine, which is consistent with the literature in which gemcitabine has not been reported to be a substrate or inhibitor/ inductor of CYP3A4, the main CYP450 isoenzyme involved in the metabolism of sunitinib and its metabolite. In addition, coadministration of sunitinib with gemcitabine did not appear to affect the PK of gemcitabine.

This treatment regimen has promising antitumor activity, surpassing that shown in the earlier gemcitabine phase I combination trial, in which 4 of 33 patients had a PR (Brell et al, 2012). Our results suggest that the combination merits further investigation in pancreatic cancer and RCC. In addition, although it is difficult to ascertain efficacy differences in a relatively small study such as this, efficacy with Schedule 2/1 appeared superior to that with Schedule $4 / 2$. This may be related to better tolerability with Schedule 2/1, allowing patients to continue on therapy longer, with fewer interruptions, particularly after the introduction of growth factor use. Furthermore, it has been hypothesised that a shorter off-treatment period (i.e., 1 week $v s 2$ weeks) may prevent tumour rebound; however, evidence for this phenomenon is limited.

The antitumor activity observed in patients with poor-risk, high grade, or sarcomatoid RCC is noteworthy. Sarcomatoid differentiation, found across all RCC histological subtypes (de PeraltaVenturina et al, 2001), is thought to represent transformation of RCC to a higher grade (Cheville et al, 2004; Golshayan et al, 2009), 


\begin{tabular}{|c|c|c|}
\hline \multicolumn{3}{|c|}{$\begin{array}{l}\text { Table } 5 \text {. Best tumour response in all patients (on all dosing s } \\
\text { and in patients on Schedule } 2 / 1 \text { post-amendment } \\
\qquad \begin{array}{l}\text { No. of patients (\%) }\end{array}\end{array}$} \\
\hline & $\begin{array}{l}\text { All patients } \\
(N=44)\end{array}$ & $\begin{array}{c}\text { Schedule } 2 / 1 \\
\text { post-amendment } \\
(N=25)\end{array}$ \\
\hline Complete response (CR) & 0 & 0 \\
\hline Partial response $(\mathrm{PR})^{\mathbf{a}}$ & $8(18)$ & $7(28)$ \\
\hline Stable disease $(\mathrm{SD})^{\mathbf{b}}$ & $18(41)$ & $12(48)$ \\
\hline Progressive disease & $10(23)$ & $5(20)$ \\
\hline Not evaluable & $3(7)$ & 0 \\
\hline Missing & $5(11)$ & $1(4)$ \\
\hline ORR (CR+PR) & $8(18)$ & $7(28)$ \\
\hline $\begin{array}{l}\text { Clinical benefit rate } \\
(\mathrm{CR}+\mathrm{PR}+\mathrm{SD})\end{array}$ & $26(59)$ & $19(76)$ \\
\hline \multicolumn{3}{|c|}{ 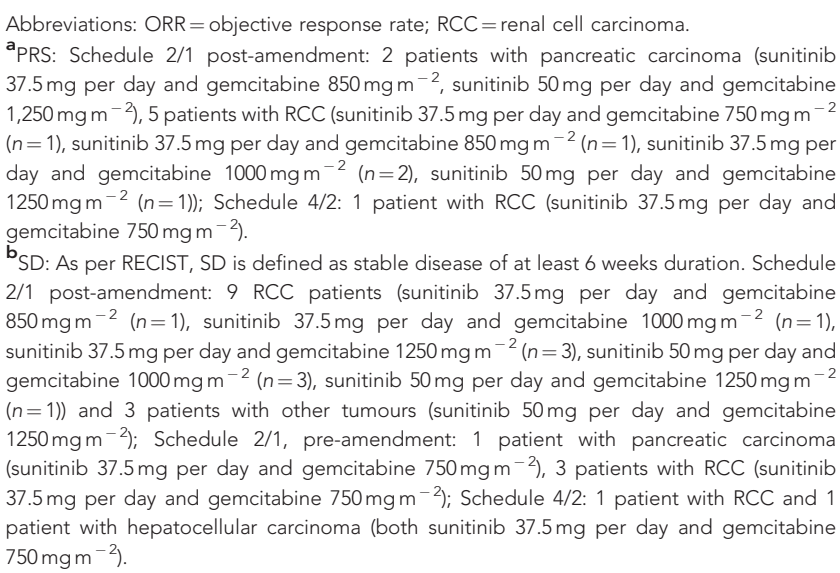 } \\
\hline
\end{tabular}

and is associated with a relatively poor prognosis and median overall survival of only $\sim 3-10$ months with non-targeted agents (e.g., immunotherapy; de Peralta-Venturina et al, 2001; Escudier et al, 2002; Mian et al, 2002; Kwak et al, 2007). Similarly, among clinical poor-risk patients, overall survival remains short (median 4-11 months) despite the proven benefit of temsirolimus (Motzer et al, 1999, 2002; Hudes et al, 2007). There is no standard treatment for sarcomatoid RCC patients, and new treatment options for both of these particularly challenging RCC subgroups are urgently needed. In our study, all of the RCC patients who were poor risk and/or had high grade or sarcomatoid disease achieved a PR or SD with sunitinib plus gemcitabine. Although patient numbers are small, our results compare favourably with a recent retrospective analysis of patients with RCC and sarcomatoid differentiation treated with VEGF- or VEGFR-targeted therapy (Golshayan et al, 2009). In that study, 6/21 patients (29\%) treated with sunitinib achieved a PR and a further nine patients treated with sunitinib (43\%) had s.d. Our results also suggest that sunitinib combined with gemcitabine may be a more active regimen than gemcitabine-based chemotherapy, which has also shown limited activity in sarcomatoid RCC (Stadler et al, 2003; Nanus et al, 2004). A phase II trial investigating sunitinib plus gemcitabine in sarcomatoid and/or poor-risk patients with RCC (NCT00556049) is underway, and a randomized phase II study of sunitinib with/ without gemcitabine in advanced RCC with sarcomatoid features (ECOG-E1808; NCT01164228) has been initiated.

Although targeted therapies have yet to deliver significant advances in pancreatic cancer treatment (O'Reilly 2009), there are indications that combining EGFR-directed and/or antiangiogenic agents with gemcitabine may be beneficial (Moore et al, 2007; Van Cutsem et al, 2009). The two PRs reported in pancreatic cancer patients in our study offer encouragement, and a randomized phase II trial comparing gemcitabine with/without sunitinib is ongoing in this indication (NCT00673504). Improved patient selection based on identification of predictive biomarkers may be critical for determining patient subsets likely to derive meaningful clinical benefit from combinations of cytotoxic and targeted therapy.

In conclusion, patients with advanced solid malignancies for whom curative therapy was not available tolerated sunitinib and gemcitabine at the maximum approved doses of each agent on Schedule 2/1 with growth factor support. Preliminary antitumor data suggest clinical benefit in patients with particular malignancies, including poor-risk RCC. Phase II studies of this combination in patients with RCC or pancreatic cancer are underway.

\section{ACKNOWLEDGEMENTS}

This study was sponsored by Pfizer, Inc. We thank all of the participating patients and their families, as well as the investigators, research nurses, study coordinators, and operations staff. Medical writing support was provided by Andy Gannon and Lisa Cheyne at ACUMED (Tytherington, UK) and was funded by Pfizer Inc.

\section{CONFLICT OF INTEREST}

$\mathrm{AXZ}$ and $\mathrm{McD}$ have reported receiving consultant or advisory fees from Pfizer. LT, SP, and AR-G are full-time employees of Pfizer and hold Pfizer stock. The remaining authors declare no conflict of interest.

\section{REFERENCES}

Abrams TJ, Lee LB, Murray LJ, Pryer NK, Cherrington JM (2003)

SU11248 inhibits KIT and platelet-derived growth factor receptor beta in preclinical models of human small cell lung cancer. Mol Cancer Ther 2: 471-478.

Brell JM, Krishnamurthi SS, Rath L, Bokar JA, Savvides P, Gibbons J, Cooney MM, Meropol NJ, Ivy P, Dowlati A (2012) Phase I trial of sunitinib and gemcitabine in patients with advanced solid tumors. Cancer Chemother Pharmacol 70: 547-553.

Burstein HJ, Elias AD, Rugo HS, Cobleigh MA, Wolff AC, Eisenberg PD, Lehman M, Adams BJ, Bello CL, DePrimo SE, Baum CM, Miller KD (2008) Phase II study of sunitinib malate, an oral multitargeted tyrosine kinase inhibitor, in patients with metastatic breast cancer previously treated with an anthracycline and a taxane. J Clin Oncol 26: $1810-1816$.

Carter CA, Chen C, Brink C, Vincent P, Maxuitenko YY, Gilbert KS, Waud WR, Zhang X (2007) Sorafenib is efficacious and tolerated in combination with cytotoxic or cytostatic agents in preclinical models of human nonsmall cell lung carcinoma. Cancer Chemother Pharmacol 59: 183-195.

Cheville JC, Lohse CM, Zincke H, Weaver AL, Leibovich BC, Frank I, Blute ML (2004) Sarcomatoid renal cell carcinoma: an examination of underlying histologic subtype and an analysis of associations with patient outcome. Am J Surg Pathol 28: 435-441.

Chow LQ, Jonker DJ, Laurie SA, Call JA, Diab SG, Goss G, McWilliam M, Wang E, Chao R, Eckhardt SG, Camidge DR (2008) Sunitinib (SU) in combination with pemetrexed $(\mathrm{P})$ in patients (pts) with advanced solid malignancies: A phase I dose escalation study. J Clin Oncol 26(May 20 suppl) (abstr. 3566).

Christensen JG, Hall C, Hollister BA (2008) Antitumor efficacy of sunitinib malate in concurrent and sequential combinations with standard chemotherapeutic agents in non-small cell lung cancer (NSCLC) 
nonclinical models. Proceedings of the 99th Annual Meeting of the American Association for Cancer Research. (Abstract 1433).

de Peralta-Venturina M, Moch H, Amin M, Tamboli P, Hailemariam S, Mihatsch M, Javidan J, Stricker H, Ro JY, Amin MB (2001) Sarcomatoid differentiation in renal cell carcinoma: a study of 101 cases. Am J Surg Pathol 25: 275-284.

Demetri GD, van Oosterom AT, Garrett CR, Blackstein ME, Shah MH, Verweij J, McArthur G, Judson IR, Heinrich MC, Morgan JA, Desai J, Fletcher CD, George S, Bello CL, Huang X, Baum CM, Casali PG (2006) Efficacy and safety of sunitinib in patients with advanced gastrointestinal stromal tumour after failure of imatinib: a randomised controlled trial. Lancet 368: 1329-1338.

Escudier B, Droz JP, Rolland F, Terrier-Lacombe MJ, Gravis G, Beuzeboc P, Chauvet B, Chevreau C, Eymard JC, Lesimple T, Merrouche Y, Oudard S, Priou F, Guillemare C, Gourgou S, Culine S. on behalf of the Genitourinary Group of the French Federation of Cancer Centers (2002) Doxorubicin and ifosfamide in patients with metastatic sarcomatoid renal cell carcinoma: a phase II study of the Genitourinary Group of the French Federation of Cancer Centers. J Urol 168: 959-961.

Escudier B, Szczylik C, Hutson TE, Demkow T, Staehler M, Rolland F, Negrier S, Laferriere N, Scheuring UJ, Cella D, Shah S, Bukowski RM (2009) Randomized phase II trial of first-line treatment with sorafenib versus interferon alfa-2a in patients with metastatic renal cell carcinoma. J Clin Oncol 27: 1280-1289.

Faivre S, Delbaldo C, Vera K, Robert C, Lozahic S, Lassau N, Bello C, Deprimo S, Brega N, Massimini G, Armand JP, Scigalla P, Raymond E (2006) Safety, pharmacokinetic, and antitumor activity of SU11248, a novel oral multitarget tyrosine kinase inhibitor in patients with cancer. J Clin Oncol 24: 25-35.

Gemzar $^{\circledR}$ (gemcitabine HCI) product monograph. Eli Lilly Canada, Toronto, Ontario, Canada (revised February 2006) .

Gemzar $^{\circledR}$ (gemcitabine $\mathrm{HCl}$ ) prescribing information. Eli Lilly and Company, Indianapolis, IN, USA (revised March 2010) .

Golshayan AR, George S, Heng DY, Elson P, Wood LS, Mekhail TM, Garcia JA, Aydin H, Zhou M, Bukowski RM, Rini BI (2009) Metastatic sarcomatoid renal cell carcinoma treated with vascular endothelial growth factor-targeted therapy. J Clin Oncol 27: 235-241.

Heath EI, Blumenschein GR, Cohen RB, LoRusso PM, LoConte NK, Kim ST, Chao R, Wilding G (2008) Phase I study of sunitinib in combination with carboplatin (C) plus paclitaxel (P) in patients (pts) with advanced solid tumors (STs). J Clin Oncol 26(May 20 suppl) (abstr. 3565).

Hudes G, Carducci M, Tomczak P, Dutcher J, Figlin R, Kapoor A, Staroslawska E, Sosman J, McDermott D, Bodrogi I, Kovacevic Z, Lesovoy V, Schmidt-Wolf IG, Barbarash O, Gokmen E, O'Toole T, Lustgarten S, Moore L, Motzer RJ. on behalf of the Global ARCC Trial (2007) Temsirolimus, interferon alfa, or both for advanced renal-cell carcinoma. N Engl J Med 356: 2271-2281.

Hurwitz HI, Fehrenbacher L, Hainsworth JD, Heim W, Berlin J, Holmgren E, Hambleton J, Novotny WF, Kabbinavar F (2005) Bevacizumab in combination with fluorouracil and leucovorin: an active regimen for first-line metastatic colorectal cancer. J Clin Oncol 23: 3502-3508.

Kulke M, Lenz HJ, Meropol N, Posey J, Ryan DP, Picus J, Bergsland E, Stuart K, Tye L, Huang X, Li JZ, Baum CM, Fuchs CS (2008) Activity of sunitinib in patients with advanced neuroendocrine tumors. J Clin Oncol 26: 3403-3410.

Kwak C, Park YH, Jeong CW, Jeong H, Lee SE, Moon KC, Ku JH (2007) Sarcomatoid differentiation as a prognostic factor for immunotherapy in metastatic renal cell carcinoma. J Surg Oncol 95: 317-323.

Manegold C, von Pawel J, Zatloukal P, Ramlau R, Gorbounova V, Hirsh V, Leighl N, Mezger J, Archer V, Reck M (2008) BO17704 (AVAIL): A phase III randomised study of first-line bevacizumab combined with cisplatin/gemcitabine (CG) in patients (pts) with advanced or recurrent non-squamous, non-small cell lung cancer (NSCLC). Ann Oncol 19, LBA1.

Mendel DB, Laird AD, Xin X, Louie SG, Christensen JG, Li G, Schreck RE, Abrams TJ, Ngai TJ, Lee LB, Murray LJ, Carver J, Chan E, Moss KG, Haznedar JO, Sukbuntherng J, Blake RA, Sun L, Tang C, Miller T, Shirazian S, McMahon G, Cherrington JM (2003) In vivo antitumor activity of SU11248, a novel tyrosine kinase inhibitor targeting vascular endothelial growth factor and platelet-derived growth factor receptors: determination of a pharmacokinetic/pharmacodynamic relationship. Clin Cancer Res 9: 327-337.

Mian BM, Bhadkamkar N, Slaton JW, Pisters PW, Daliani D, Swanson DA, Pisters LL (2002) Prognostic factors and survival of patients with sarcomatoid renal cell carcinoma. J Urol 167: 65-70.
Miller K, Wang M, Gralow J, Dickler M, Cobleigh M, Perez EA, Shenkier T, Cella D, Davidson NE (2007) Paclitaxel plus bevacizumab versus paclitaxel alone for metastatic breast cancer. $N$ Eng J Med 357: 2666-2676.

Moore MJ, Goldstein D, Hamm J, Figer A, Hecht JR, Gallinger S, Au HJ, Murawa P, Walde D, Wolff RA, Campos D, Lim R, Ding K, Clark G, Voskoglou-Nomikos T, Ptasynski M, Parulekar W. on behalf of the National Cancer Institute of Canada Clinical Trials Group (2007) Erlotinib plus gemcitabine compared with gemcitabine alone in patients with advanced pancreatic cancer: a phase III trial of the National Cancer Institute of Canada Clinical Trials Group. J Clin Oncol 25: 1960-1966.

Motzer RJ, Bacik J, Murphy BA, Russo P, Mazumdar M (2002) Interferon-alfa as a comparative treatment for clinical trials of new therapies against advanced renal cell carcinoma. J Clin Oncol 20: 289-296.

Motzer RJ, Hutson TE, Tomczak P, Michaelson MD, Bukowski RM, Rixe O, Oudard S, Negrier S, Szczylik C, Kim ST, Chen I, Bycott PW, Baum CM, Figlin RA (2007) Sunitinib versus interferon alfa in metastatic renal-cell carcinoma. N Engl J Med 356: 115-124.

Motzer RJ, Mazumdar M, Bacik J, Berg W, Amsterdam A, Ferrara J (1999) Survival and prognostic stratification of 670 patients with advanced renal cell carcinoma. J Clin Oncol 17: 2530-2540.

Motzer RJ, Michaelson MD, Redman BG, Hudes GR, Wilding G, Figlin RA, Ginsberg MS, Kim ST, Baum CM, DePrimo SE, Li JZ, Bello CL, Theuer CP, George DJ, Rini BI (2006) Activity of SU11248, a multitargeted inhibitor of vascular endothelial growth factor receptor and plateletderived growth factor receptor, in patients with metastatic renal cell carcinoma. J Clin Oncol 24: 16-24.

Nanus DM, Garino A, Milowsky MI, Larkin M, Dutcher JP (2004) Active chemotherapy for sarcomatoid and rapidly progressing renal cell carcinoma. Cancer 101: 1545-1551.

Okamoto I, Shimizu T, Miyazaki M, Tsurutani J, Ichikawa Y, Terashima M, Takeda M, Fumita S, Ohki E, Kimura N, Hashimoto J, Nakagawa K (2012) Feasibility study of two schedules of sunitinib in combination with pemetrexed in patients with advanced solid tumors. Invest New Drugs 30: 639-646.

O'Farrell AM, Abrams TJ, Yuen HA, Ngai TJ, Louie SG, Yee KW, Wong LM, Hong W, Lee LB, Town A, Smolich BD, Manning WC, Murray LJ, Heinrich MC, Cherrington JM (2003a) SU11248 is a novel FLT3 tyrosine kinase inhibitor with potent activity in vitro and in vivo. Blood 101: 3597-3605.

O'Farrell AM, Foran JM, Fiedler W, Serve H, Paquette RL, Cooper MA, Yuen HA, Louie SG, Kim H, Nicholas S, Heinrich MC, Berdel WE, Bello C, Jacobs M, Scigalla P, Manning WC, Kelsey S, Cherrington JM (2003b) An innovative phase I clinical study demonstrates inhibition of FLT3 phosphorylation by SU11248 in acute myeloid leukemia patients. Clin Cancer Res 9: 5465-5476.

O'Reilly EM (2009) Pancreatic adenocarcinoma: new strategies for success. Gastrointest Cancer Res 3(suppl 1): S11-S15.

Raymond E, Dahan L, Raoul JL, Bang YJ, Borbath I, Lombard-Bohas C, Valle J, Metrakos P, Smith D, Vinik A, Chen JS, Hörsch D, Hammel P, Wiedenmann B, Van Cutsem E, Patyna S, Lu DR, Blanckmeister C, Chao R, Ruszniewski P (2011) Sunitinib malate for the treatment of pancreatic neuroendocrine tumors. N Engl J Med 364: 501-513.

Reck M, Frickhofen N, Cedres S, Gatzemeier U, Heigener D, Fuhr HG, Thall A, Lanzalone S, Stephenson P, Ruiz-Garcia A, Chao R, Felip E (2010) Sunitinib in combination with gemcitabine plus cisplatin for advanced non-small cell lung cancer: a phase I dose-escalation study. Lung Cancer 70: $180-187$.

Rosen L, Mulay M, Long J, Wittner J, Brown J, Martino A-M, Bello CL, Walter S, Scigalla P, Zhu J (2003) Phase I trial of SU11248, a novel tyrosine kinase inhibitor in advanced solid tumors. Proc Am Soc Clin Oncol 22: 191

Sandler A, Gray R, Perry MC, Brahmer J, Schiller JH, Dowlati A, Lilenbaum R, Johnson DH (2006) Paclitaxel-carboplatin alone or with bevacizumab for non-small-cell lung cancer. N Engl J Med 355: 2542-2550.

Scagliotti GV, Krzakowski M, Szczesna A, Strausz J, Makhson A, Reck M, Wierzbicki RF, Albert I, Thomas M, Miziara JE, Papai ZS, Karaseva N, Thongprasert S, Portulas ED, von Pawel J, Zhang K, Selaru P, Tye L, Chao RC, Govindan R (2012) Sunitinib plus erlotinib versus placebo plus erlotinib in patients with previously treated advanced non-small-cell lung cancer: a phase III trial. J Clin Oncol 30: 2070-2078. 
Socinski MA, Novello S, Brahmer JR, Rosell R, Sanchez JM, Belani CP, Govindan R, Atkins JN, Gillenwater HH, Pallares C, Tye L, Selaru P, Chao RC, Scagliotti GV (2008) Multicenter, phase II trial of sunitinib in previously treated, advanced non-small-cell lung cancer. J Clin Oncol 26: 650-656.

Stadler WM, Huo D, George C, Yang X, Ryan CW, Karrison T, Zimmerman TM, Vogelzang NJ (2003) Prognostic factors for survival with gemcitabine plus 5-fluorouracil based regimens for metastatic renal cancer. J Urol 170: $1141-1145$.

SUTENT (sunitinib malate) prescribing information. Pfizer Inc., New York, NY, USA (2012) pp 1-30.

Sweeney C, Verschraegen C, Chiorean G, Lee F, Jones S, Tye L, Bello A, Chao R, Burris H (2007) A phase I dose escalation study of sunitinib plus capecitabine in patients with advanced solid tumors. J Clin Oncol 25 (June 20 suppl.(abstr. 3592).

Therasse P, Arbuck SG, Eisenhauer EA, Wanders J, Kaplan RS, Rubinstein L, Verweij J, Van Glabbeke M, van Oosterom AT, Christian MC, Gwyther SG (2000) New guidelines to evaluate the response to treatment in solid tumors. J Natl Cancer Inst 92: 205-216.

Supplementary Information accompanies this paper on British Journal of Cancer website (http://www.nature.com/bjc)
Traynor AM, Sandler AB, Schiller JH, Ilagan J, Vermeulen WL, Liu G, Tye L, Verkh L, Chao R, Robert F (2008) Phase I dose-escalation and pharmacokinetic (PK) study of sunitinib (SU) plus docetaxel (D) in patients (pts) with advanced solid tumors (STs). J Clin Oncol 26(May 20 suppl) (abstr. 3564).

Van Cutsem E, Vervenne WL, Bennouna J, Humblet Y, Gill S, Van Laethem JL, Verslype C, Scheithauer W, Shang A, Cosaert J, Moore MJ (2009) Phase III trial of bevacizumab in combination with gemcitabine and erlotinib in patients with metastatic pancreatic cancer. J Clin Oncol 27: 2231-2237.

Yee KW, Schittenhelm M, O’Farrell AM, Town AR, McGreevey L, Bainbridge T, Cherrington JM, Heinrich MC (2004) Synergistic effect of SU11248 with cytarabine or daunorubicin on FLT3 ITD-positive leukemic cells. Blood 104: 4202-4209.

This work is published under the standard license to publish agreement. After 12 months the work will become freely available and the license terms will switch to a Creative Commons AttributionNonCommercial-Share Alike 3.0 Unported License. 